PNL-10383

UC-350

\title{
THE SPECIFICATION AND ESTIMATION OF TECHNOLOGICAL CHANGE IN ELECTRICITY PRODUCTION
}

D. C. Kavanaugh

W. B. Ashton

January 1995

Prepared for the U. S. Department of Energy under Contract DE-AC06-76RLO 1830

Pacific Northwest Laboratory Richland, Washington 99352 



\section{DISCLAIMER}

This report was prepared as an account of work sponsored by an agency of the United States Government. Neither the United States Government nor any agency thereof, nor any of their employees, make any warranty, express or implied, or assumes any legal liability or responsibility for the accuracy, completeness, or usefulness of any information, apparatus, product, or process disclosed, or represents that its use would not infringe privately owned rights. Reference herein to any specific commercial product, process, or service by trade name, trademark, manufacturer, or otherwise does not necessarily constitute or imply its endorsement, recommendation, or favoring by the United States Government or any agency thereof. The views and opinions of authors expressed herein do not necessarily state or reflect those of the United States Government or any agency thereof. 


\section{DISCLAIMER}

Portions of this document may be illegible in electronic image products. Images are produced from the best available original document. 


\section{Summary}

This study focuses on the rate of technological change in electricity production. The dominant role of fossil fuel-fired electricity production in the industry, coupled with the direct association with the emission of greenhouse gases, makes technology parameters particularly significant for several reasons. First, very long-run simulations of energy-economic paths at a global level require that technical progress occupy a place in the methodology for sound formulations that are vital in global emissions/energy policy analysis. Second, given the outlook for electricity generation being predominately coal-based, especially in developing economies around the world, the specification and measurement of technical change is essential for developing realistic long-run technology forecasts. Finally, industry or sector growth in productivity hinges partly on technical progress, and updated analysis will always be necessary to stay abreast of developments on this front, as well as for economic growth considerations in general.

This study is based on empirical economic research on production functions in the electric utility industry. However, it advances a seldom used approach, called the "engineeringproduction function," in contrast to the more common neoclassical approach used by economists. Combined with this approach is a major departure from the type of data used to conduct econometric estimations of production parameters. This research draws upon a consistent set of $e x$ ante or "blueprint" data that better reflects planned, technical performance and cost data elements, in contrast to the more customary, ex post type of data from actual firm/plant operations.

The results from the examination of coal-fired technologies indicate the presence of technical change. Using data for the period from 1979 to 1989 , we find technical change to be capital-augmenting at the rate of 1.8 percent per year. Technical advance diminishes fuel inputs, however. (Labor factors of production are not present in the specifications, given their very low cost share in the cost of installation and production.) The composite rate of technical progress is found to be 0.7 percent per year. Our estimates fall within the range of other studies, which are briefly reviewed in the report.

This study is sponsored by internal Laboratory resources under the direction of the Global Studies Program. 



\section{Table of Contents}

Summary $\ldots \ldots \ldots \ldots \ldots \ldots \ldots \ldots \ldots \ldots \ldots \ldots \ldots \ldots \ldots \ldots \ldots \ldots \ldots \ldots \ldots$ iii

1.0 Introduction $\ldots \ldots \ldots \ldots \ldots \ldots \ldots \ldots \ldots \ldots \ldots \ldots \ldots \ldots \ldots \ldots \ldots \ldots \ldots$

2.0 A Survey of Studies on Production and Technical Change in the Electric Industry .... 3

3.0 The Analytical Approach to Empirically Modeling Technical Change . . . . . . . . . 7

4.0 The Data for Model Estimation $\ldots \ldots \ldots \ldots \ldots \ldots \ldots \ldots \ldots \ldots \ldots$

5.0 Empirical Results $\ldots \ldots \ldots \ldots \ldots \ldots \ldots \ldots \ldots \ldots \ldots \ldots \ldots \ldots \ldots \ldots$

6.0 Conclusions $\ldots \ldots \ldots \ldots \ldots \ldots \ldots \ldots \ldots \ldots \ldots \ldots \ldots \ldots \ldots \ldots \ldots \ldots$

7.0 References $\ldots \ldots \ldots \ldots \ldots \ldots \ldots \ldots \ldots \ldots \ldots \ldots \ldots \ldots \ldots \ldots \ldots \ldots$

Appendix A: Data Sources $\ldots \ldots \ldots \ldots \ldots \ldots \ldots \ldots \ldots \ldots \ldots \ldots \ldots \ldots \ldots \ldots \ldots \ldots$

Tables

Table 2.1 Summary of Selected Results on Technical Change $\ldots \ldots \ldots \ldots \ldots \ldots$

Table 5.1 Regression Results $\ldots \ldots \ldots \ldots \ldots \ldots \ldots \ldots \ldots \ldots \ldots \ldots \ldots \ldots \ldots$

Table 5.2 Technical Change Estimates $\ldots \ldots \ldots \ldots \ldots \ldots \ldots \ldots \ldots \ldots \ldots \ldots$

Table 5.3 Model Extensions $\ldots \ldots \ldots \ldots \ldots \ldots \ldots \ldots \ldots \ldots \ldots \ldots \ldots \ldots \ldots$ 


\subsection{Introduction}

Fossil fuel-fired steam electric generation represents a dominant portion of the technology employed for electricity production on both a worldwide and a national basis. Greenhouse gas emissions associated with the combustion of these fuels underlie an especially significant role in global climate change analyses and policy formulation. Among the hydro-carbon fuels, coalfired generation technologies represent by far the largest for baseload generation. More importantly, they are expected to occupy an even more prominent role in the future. This is largely the combined result of the production costs of coal-fired generation and increasing electricification in less-developed country (LDC) economies around the globe.

The evolution of energy in economic growth and development will rest on technological advances. To gain an understanding of very long-run forces that will affect these energy/economic growth paths, knowledge about the nature and rate of technological progress in some major sectors of an economic system are vital. Electricity production is one of these sectors and, moreover, data for the industry are comparatively rich for empirical work.

Four features or characteristics of the general production function relationship traditionally receive concentration. First, the efficiency of the technology is represented by the location of the production surface in input space. Second, there is the technologically determined degree of homogeneity or returns to scale. This is output elasticity with respect to relative changes in inputs during the period of production (or in the dual, the reduction in total costs). Third, is the degree of factor intensity reflected by a "skewing" of production toward one particular input. Fourth is the degree of factor substitutability among inputs in maintaining a given rate of output.

Technical progress places these features into a temporal context best imagined as a shift in the production surface. It is this temporal dimension that lies at the heart of such varied, but interrelated, issues as economic growth, productivity/international competitiveness and research and development impacts. Technical change represents the elements of a change or alteration of production over time that permits the production of more output, or alternatively, the use of less inputs to produce the same amount of output because its efficiency is greater. A shift that has equally proportionate effects on inputs is defined as neutral technological change. If the production function shifts because of technical progress such that one factor becomes dispropor- 
tionately more efficient in production than the other inputs, technical change is said to be factor-augmenting.

The economic theory of technological change has also refined several other characterizations of technical progress. Technical change is considered non-neutral or biased if the change brings about a relative increase in the cost-share of factor (factor-using technical change), or is factor-saving if the input's cost-share falls. Technical progress is also differentiable by the manner in which it is manifested in techniques and inputs. Change is disembodied if there is a uniform effect across all inputs of a given type (all capital, all labor, all energy or all materials inputs). If, for example, progress is manifested in different ages of machines, it is embodied technical change. Finally, change can be considered as exogenous, in which case it just happens naturally, or it can be endogenous, where its evolution is determined partly by economic forces.

This paper discusses technological change in electricity production within the context of empirical economic research on production functions in the electric utility industry. Section 2 surveys the work done by empirical economists over the last 40 years. Section 3 compares the econometric approaches of the past to the engineering-production function used for the empirical specifications in this study. Section 4 discusses the data used to estimate the parameters of production in the optimization model. Section 5 summarizes the empirical results for several samples of cost/performance data for the period spanning from 1979 to 1989 . Conclusions follow in section 6 . 


\subsection{A Survey of Studies on Production and Technical Change in the Electric Industry}

The electric power industry in the U.S., as well as elsewhere, has been a particularly fertile one for empirical work done by economists. This stems largely from a comparatively rigorous regulatory oversight at the state and federal level. Data reporting requirements have provided analysts with a wealth of information on the industry with which to examine a very broad array of industry, economic/engineering and regulatory issues. Empirical work on the industry "production function" has occupied a prominent place in this research. It has also been has largely responsible for the application of more flexible/informative models of production to explain industry behavior, in general. This is due, in part, to the breadth and quality of data. The purpose of the brief survey below is twofold. First, it highlights the major econometric findings achieved on matters relating to the structure of production for this highly capital and fuelintensive sector. Second, it serves to juxtapose the type of data typically used in these studies with the data advanced and used here. As a result, the limitations of the former and the advantages of the latter will be highlighted.

The seminal work on the steam-electric industry production function is that of M. Nerlove [1963]. While other empirical studies of the production function pre-date Nerlove's work, his was particularly pioneering in the sense that it served to demonstrate how duality theory could be used to permit tractable, yet rigorous, estimation of the parameters of production. Using a cross section of data at the firm level for the year 1955, Nerlove estimated generally that the industry reflected increasing returns to scale. However, his results suggested that returns varied inversely with size/output (non-homogeneity). Second, to the extent that there are presumably different vintages of capacity embodied in the capital stock across firms in the study year, there is, however, no indication of a bias from technological progress in the input mix used in generation. No explicit estimate of the rate of such progress is possible from the Nerlove results; however, since the firm was the level of observation, this blurs resource mix and vintage elements.

P. Dhrymes and M. Kurz (1964) made another attempt at exploiting duality to permit estimation of the industry's production. Dhrymes and Kurz (DK) estimated a constant elasticisty of substitution (CES)-based set of equations using newly constructed plants across the U.S. over the period 1937-1959. DK stratified their sample according to a two-way scheme: 
technological epochs and MW-size of the plant. DK obtained increasing returns to scale (at the plant level, in contrast to the firm-level treatment in Nerlove). DK determined that the rate of technical change possessed both neutral and non-neutral components. Between the pre-1950s and post-1940s epochs, the non-neutral component represented labor-saving at the rate of about 2 percent per year.

A study from this era that is of note for its relation to our approach here is one by S. Ling (1964). Ling departed from the smooth, "neoclassical production function" approach typified by Nerlove and DK in that he took a more structured, engineering approach to the production of electricity. Ling used simulation data of system operations for a 20-year period (1938-1958) to form the basis for estimating the structure of production. Like Nerlove, his results showed increasing returns to scale; however, the specification for the cost function lacked the dynamics to account for technological change.

The work on electric power production functions in the ensuing decade is important for advances in flexible functional-form estimation based on the theoretical work of Shephard (1970) and Diewert (1974). The sophistication and generalized extensions of the structure of production theory, in general, is reflected in the work of Christensen and Greene (1976), and extended by many, including Kavanaugh and Simpson (1981). Cowing (1974) advanced Ling's engineering approach, as well, during this period. A more detailed discussion of Cowing's approach is deferred to the next section of the report because it serves as a partial basis for the analysis here. In addition to the theoretical extensions, econometric work was also devoted to investigating the input bias emanating out of rate-of-return regulation, as originally advanced in the seminal study by Averch and Johnson (1962). Among studies that share this focus with the electric-production function are Boyes (1976), Courville (1974), Petersen (1975), and Spann (1974). Unfortunately, the latter group's findings offered very few collective implications for technical change in electricity production. They are significant, however, because they illustrate that estimating technological change may not be independent of input bias due to regulation. These are only a few of the considerable stock of studies that have been conducted in electricity supply. A more detailed survey of those conducted through the 1970s can be found in the compendium by Cowing and Smith (1978).

Research on the electric-utility production function in the 1980 s broadened beyond the plane of regulatory policy, and expanded the art of production/cost estimation. Much of this 
work drew upon the earlier work on regulatory bias and formally embedded it into the flexible form formulations of production/cost functions (Cowing 1978). This broader policy focus is evident in the studies by Gollop and Roberts (1981 and 1983). Their first study possesses a productivity emphasis for the electric utility industry in the United States, while the latter is oriented to environmental regulation and policy impacts on the productivity of the industry. In Gollop and Roberts (1981), a translog flexible-form model of the utility-firm cost function is specified to estimate the role of technological change in explaining the economic growth of the utility industry. Using a small sample of utilities to obtain firm-level observations of predominately coal-fired systems over the period of 1958 to 1975, they found that technical progress was a major source of growth in the 1950s and 1960s, but a negative factor in the 1970s. They also found that technical change was neutral with respect to capital (neither capital-using nor capitalsaving), but was labor-saving and fuel-using.

In Gollop and Roberts (1983), a very similar approach is used, employing firm-level observations on 56 electric utilities over the more narrow period of 1973 to 1979. The results extended those of the earlier analysis comparably. Technical change was negative in the early 1970s (-3.7 percent), but appeared to regain a positive trend by 1979 ( 2.6 percent). One distinguishing feature in this study was the incorporation of regulatory intensity into the model. Gollop and Roberts inferred from their findings that environmental regulation accounted for a 44 percent reduction in the rate of productivity growth during this period.

Nelson and Mohar (1983) estimated a restricted return cost function along the lines developed in Cowing (1978), and they explicitly tested for the impacts between regulation and technical change. Their formulation permitted a decomposition of productivity growth in the electric industry into effects from technical progress, scale effects, and regulatory effects. Their results are consistent with other findings as to the roller-coaster behavior of productivity in the sector during the post-war era. Their results also demonstrate the dramatic impact that regulation has on estimates of total factor productivity if made explicit in the specifications.

A final study to complete this brief survey of developments on modeling electric production is Nelson's (1986). Nelson specified explicitly a cost function under a rate-of-return constraint, coupled with a more general specification of the sources of technical change - both secular or time effects and vintaging effects were permitted. Using a nested approach toward testing 
Table 2.1 Summary of Selected Results on Technical Change

\begin{tabular}{|c|c|c|c|c|}
\hline Study & Data & $\begin{array}{l}\text { Rate of Technical } \\
\text { Change }\end{array}$ & $\begin{array}{l}\text { Nature of Technical } \\
\text { Change }\end{array}$ & $\begin{array}{l}\text { Returns } \\
\text { to Scale }\end{array}$ \\
\hline Cowing(1974) & $\begin{array}{l}\text { Firm-level, 1947-1965 } \\
\text { Operations }\end{array}$ & $1.6 \%$ & $\begin{array}{l}\text { Capital Augmenting: } \\
2.3 \%\end{array}$ & 1.2 \\
\hline $\begin{array}{l}\text { Gollop-Roberts } \\
\text { (1981) }\end{array}$ & $\begin{array}{l}\text { Firm-level, 1958-1975 } \\
\text { Operations }\end{array}$ & -4.4 to $4.7 \%$ & N/A & \\
\hline $\begin{array}{l}\text { Gollop-Roberts } \\
\text { (1983) }\end{array}$ & $\begin{array}{l}\text { Firm-level, 1973-1979 } \\
\text { Operations }\end{array}$ & -2.6 to $3.7 \%$ & $\begin{array}{l}\text { Capital-Using Fuel- } \\
\text { and Labor- Saving }\end{array}$ & \\
\hline $\begin{array}{l}\text { Nelson-Mohar } \\
\text { (1983) }\end{array}$ & $\begin{array}{l}\text { Firm-level, 1950-1978 } \\
\text { Operations }\end{array}$ & -3.4 to $4.5 \%$ & N/A & $\begin{array}{c}1.03 \text { to } \\
1.08\end{array}$ \\
\hline Nelson (1986) & $\begin{array}{l}\text { Firm-level, 1961-1978 } \\
\text { Operations }\end{array}$ & $\begin{array}{l}\text { 1961-1970: } 2.4 \% \\
\text { 1971-1974: } 0.9 \% \\
\text { 1975-1978: } 4.1 \% \\
\end{array}$ & $\begin{array}{l}\text { Mixed; both Capital- } \\
\text { Using (saving) and } \\
\text { Fuel-Saving (using) }\end{array}$ & \\
\hline
\end{tabular}

for the presence and types of technical change, Nelson estimated the restricted translog cost function on firm-level data for 22 utilities over the span of 1961 to 1978 . Nelson's separation of technical change into time and vintage effects permitted an extremely insightful vehicle for measuring and interpreting the sources of technological change. He found that the most general model reflected technical change at the rates of 0.1 to 4.1 percent over sub-periods of the 18year interval, and that time effects largely dominated vintage effects. Like the findings of Gollop and Roberts (1981 and 1983), Nelson's show technical change languishing in the early $1970 \mathrm{~s}$ ( 0.1 percent), and rebounding in the period after ( 4.1 percent). The nature of technical progress, however, appears far more mixed over the sample period. Depending on the subperiod and the index model, input biases of technical progress are not uniform. Nelson interpreted the results, which suggest that technical change is capital-using and fuel-saving, as more compatible theoretically with engineering models like those of Ling and Cowing. Other inferences of capital-saving and fuel-using technical change seem more consistent with findings from the traditional economic production function analyses.

Nelson (1987) extended the same restricted data set to determine the effect of technical change on factor demands in the power industry, with results similar to his earlier findings on technical progress. Table 2.1 summarizes a selection of the studies reviewed above and highlights data types and major findings with respect to technical change. 


\subsection{The Analytical Approach to Empirically Modeling Technical Change}

The approach examined in this study rests on the engineering-production function as a rigorous guide for our empirical specifications and estimation of technical change. Conventional economic modeling of production has taken the technical possibilities of production as a given, and used output prices and input prices to determine economically optimal rate of output. In a dynamic model conventional economic modeling of production has used output prices and input prices to determine the rate of investment. The engineering-production function, in contrast, rests on process or activity analysis to solve the technological optimization problem: what processes or combinations of given inputs yield the maximum amount of output, or in the dual, the minimum cost for a given output level? The engineering-production function, therefore, derives the production surface that the economic optimization problem takes as a given or as already being solved. Thus, econometric estimates of technical change with data supporting or associated with the design/blueprint stages of production processes may provide far less ambiguous estimates than those based on actual operation or ex post observations, which may be affected by management and regulatory factors. Moreover, many of the studies, such as those conducted by Gollop and Roberts and by Nelson, use selected utility companies in their samples, which reflect only a dominant use of coal-fired steam generation. However, in the case of timevarying demands a mixture of baseload and intermediate/peaking types of capacities may direct combustion (as in combustion turbines that operate for short durations and possess lower installed capacity costs). Thus, the firm-level data on operation is not likely to represent exclusively coal-based generation. Production cost data should be adjusted accordingly.

The prototypes for our approach are based on Ling (1964) and Cowing (1974), (predominately the latter). Other examples of the approach are available; see Chenery (1949). When combined with suitable data on the industry, the engineering or process approach obviates the need to recognize the rate-of-return constraint jointly in model estimation, as originally developed in Cowing (1978) and extended by Nelson and Mohar (1983).

Cowing's extension of the engineering-production function approach relies on specifying the production process or activity that uses three factor inputs: fuel for plant operation, capital contained in the boiler-steam turbine-generator, and labor for operation and maintenance. $A$ testable model is derived from a cost function for building and running a plant that satisfies the 
usual regularity conditions. Minimizing the present worth of the stream of costs for plant installation and operation provides the following reduced-form equations:

$$
\begin{aligned}
& H^{*}=A_{1}\left(p_{F} / p_{K}\right)^{\alpha} \exp (B V i n t a g e) \\
& M^{*}=A_{2}\left(p_{F} / p_{K}\right)^{\phi} \exp (\delta \text { Vintage })
\end{aligned}
$$

Where

$$
\begin{aligned}
& \text { HR = unit heat rate } \\
& P_{F}=\text { fuel price in Kwh equivalents } \\
& P_{K}=\text { capacity cost in Kwh equivalents. }
\end{aligned}
$$

$H^{*}$ and $M W^{*}$ are, therefore, the optimal thermal efficiency and the optimal unit size, respectively, as functions of the fuel/capital price ratio and an index of vintage of the machine. Equations (1) and (2) become linear when taking logs of both sides:

$$
\begin{aligned}
& \ln (H R)=a_{1}+\alpha \ln \left(p_{F} / p_{K}\right)+B \text { Vintage }+\epsilon \\
& \ln (M W)=a_{2}+\phi \ln \left(p_{F} / p_{K}\right)+\delta \text { Vintage }+v \\
& \epsilon \text { and } v \text { are iid as } N\left(0, \sigma_{\epsilon}^{2}\right) \text { and } N\left(0, \sigma_{v}^{2}\right), \text { respectively. }
\end{aligned}
$$

Cowing makes a case for the model representing ex ante elements that are more closely tied to the process analysis involved in the technological optimizing problem. However, like many studies, Cowing's also relies on the first two years of actual plant data as proxies of ex ante observations on plant design/operation. His results from estimating equations (3) and (4) on plant data for the period from 1947 to 1965 are summarized in the first row of Table 2.1.

The structural parameters of technical change are derived from equations (3) and (4). The relative change in scale-augmenting technical progress over a selected interval is defined from the reduced-form coefficients according to

$$
\delta-B \text {, }
$$

and the rate of fuel-augmenting technical change is estimated directly as $B$. The returns to scale parameter (indicating the output elasticity due to a change in inputs) is

$$
\delta /(\delta-B) \text {. }
$$




\subsection{The Data for Model Estimation}

As summarized in Table 2.1, the picture from the estimates of technical change is quite varied. In some cases, we can presume that technical progress may even decay. This prospect is more closely associated with business cycles and may suffer from inherent biases in model specifications.

The econometric literature has reflected the important difference between ex post and ex ante observations for both firm- and plant-level data to support the estimation of economicproduction function. Ex post data are merely observations on the actual operations decisions with plants already installed and taken as a given. Scale and factor substitution are generally much more restricted in such a short-run focus. Moreover, decision-making at the firm-level in such an ex post context can reflect considerations beyond optimal input combinations in the short-run. For instance, regulatory constraints may cause departures from a less constrained optima, but may now be "optimal." Traditionally, analysts have sought ex ante data on firm or plant operations.

This study advances a considerably different type of data with which to estimate the parameters of production. Instead of developing a database of operations data (either ex post observations or firm/plant operations in the first one or two years of operation), we rely on a consistent set of design data over time. These are "blueprint" or technical data that OEM suppliers use in bidding for construction of new thermal generating plants.

The primary data source is the Electric Power Research Institute's (EPRI) Technical Assessment Guide (TAG), [1977, 1979, 1984, and 1989]. For each generation technology, the $T A G$ reports a broad range of cost and performance characteristics. The following coal-fired technologies are represented in the estimation data base:

- coal-steam - subcritical, wet limestone flue gas desulfurization (bituminous and subbituminous)

- coal-steam - supercritical, wet limestone flue gas desulfurization (bituminous and subbituminous)

- coal-steam pulverized, flue gas desulfurization

- coal-steam, atmospheric fluidized bed combustion 
- coal-steam, pressurized fluidized bed, combined cycle

- coal gasification, combined cycle. 


\subsection{Empirical Results}

Equations (3) and (4) are estimated on the time series of EPRI cross-section data using ordinary least squares (OLS), given that these are reduced form specifications. Table 5.1 reports the regression results for several, alternative samples of the cost/performance data for the period spanning from 1979 to 1989.

While the implications of the regression estimates for the parameters governing technical change are primary here, a brief comment about the direct regression results should be made. In the estimated equations, theory would lead us to anticipate a negative coefficient on the price ratio variable in the thermal efficiency equation, and a positive sign in the scale equation. For the pooled model (which an F-test indicates is statistically acceptable over the independent, annual models at the 95 percent confidence level) the coefficients are correct in sign, but only statistically significant for the scale equation. The yearly regression reflect some of the variability in the strength and estimated signs: the thermal efficiency equation has the wrong sign in two of the four yearly equations, while the sign on the price ratio is incorrect in the scale regressions only once. However, in none of these instances are the coefficients statistically significant from zero, and moreover, the data suggests that there are no significant differences across the years in contrast to pooling.

The equations explain only a modest amount of the variation in the engineering cost data. While implications for the optimal factor functions are interesting, it is most likely attributed to the relatively small number of observations in the sample.

Table 5.2 reports the findings for the structural estimates of technical change and for unit economies of scale that can be derived according to Equations (5) to (7). As for Table 5.1, the results for the pooled estimates for the 1979 to 1989 period should be emphasized. There, we see that technical change in coal-fired technologies augmented capital by a total of 19.1 percent, or at an annual rate of 1.8 percent per year. Using factor cost shares for the period and the scale economies estimate of 0.82 (suggesting that unit-sized economies of scale have been exhausted), for a 10 percent increase in MW-size, there is only an 8.2 percent increase in output. (a) The annual rate of composite technical change is found to be 0.7 percent. While signifi-

(a) Or a 10 percent increase in all inputs leads to 22 percent increase in the costs of producing output. 
cant, this estimate is considerably below those obtained in studies that examined data from the late 1970s. Though the estimates obtained from these are not negative, they appear to reflect some stagnation in technical progress.

When departures from the pooled results of Tables 5.1 and 5.2 are made, the inferences become markedly disparate. ${ }^{(a)}$ For the two early years of the sample (1979 and 1982, in columns 2 and 3 of Table 5.2), the findings are comparable to those for the pooled results. In fact, the estimated annual rate of composite technical change is relatively high for these yearly models: 4.2 percent and 5.2 percent for 1979 and 1982, respectively. These rates, while very high in relation to the pooled results, are comparable to some of the rates obtained for the industry in other research for the latter part of the 1970s. The estimates for the years 1986 and 1989, however, are decidedly more troublesome from a stability point of view. The technical change interpretations from the yearly regressions for these years are extremely perverse. Coupled with the statistical test which justifies pooling, the results in the last column are probably the most reasonable estimates from the sample.

(a) Various pooling of sub-periods produced largely comparable outcomes and are not discussed here. Additional detail is available from the first author. 
Table 5.1 Regression Results

\begin{tabular}{|c|c|c|c|c|c|c|c|c|c|c|}
\hline \multirow[t]{2}{*}{ Variable } & \multicolumn{2}{|c|}{1979} & \multicolumn{2}{|c|}{1982} & \multicolumn{2}{|c|}{1986} & \multicolumn{2}{|c|}{1989} & \multicolumn{2}{|c|}{ Pooled } \\
\hline & $\begin{array}{l}\text { Thermal } \\
\text { Efficiency }\end{array}$ & $\begin{array}{c}\text { Optimal } \\
\text { Scale }\end{array}$ & $\begin{array}{l}\text { Thermal } \\
\text { Efficiency }\end{array}$ & $\begin{array}{c}\text { Optimal } \\
\text { Scale }\end{array}$ & $\begin{array}{l}\text { Thermal } \\
\text { Efficiency }\end{array}$ & $\begin{array}{c}\text { Optimal } \\
\text { Scale }\end{array}$ & $\begin{array}{l}\text { Thermal } \\
\text { Efficiency }\end{array}$ & $\begin{array}{c}\text { Optimal } \\
\text { Scale }\end{array}$ & $\begin{array}{l}\text { Thermal } \\
\text { Efficiency }\end{array}$ & $\begin{array}{c}\text { Optimal } \\
\text { Scale }\end{array}$ \\
\hline Constant & $\begin{array}{c}7.68 \\
(1.21)\end{array}$ & $\begin{array}{c}8.26 \\
(5.98)\end{array}$ & $\begin{array}{c}9.37 \\
(0.75)\end{array}$ & $\begin{array}{c}4.43 \\
(4.25)\end{array}$ & $\begin{array}{c}8.96 \\
(0.71)\end{array}$ & $\begin{array}{c}9.89 \\
(2.62)\end{array}$ & $\begin{array}{c}8.72 \\
(0.52)\end{array}$ & $\begin{array}{l}14.98 \\
(3.78)\end{array}$ & $\begin{array}{c}8.99 \\
(0.25)\end{array}$ & $\begin{array}{c}10.8 \\
(1.43)\end{array}$ \\
\hline Vintage & $\begin{array}{l}-0.045 \\
(0.021)\end{array}$ & $\begin{array}{l}0.091 \\
(0.11)\end{array}$ & $\begin{array}{r}-0.067 \\
(0.02)\end{array}$ & $\begin{array}{c}0.14 \\
(0.11)\end{array}$ & $\begin{array}{l}-0.032 \\
(0.022)\end{array}$ & $\begin{array}{r}-0.004 \\
(0.08)\end{array}$ & $\begin{array}{r}-0.07 \\
(0.05)\end{array}$ & $\begin{array}{l}-0.08 \\
(0.40)\end{array}$ & $\begin{array}{r}-0.035 \\
(0.009)\end{array}$ & $\begin{array}{c}0.16 \\
(0.05)\end{array}$ \\
\hline $\mathbf{R}^{2}$ & 0.49 & 0.12 & 0.65 & 0.20 & 0.24 & 0.24 & 0.29 & 0.47 & 0.30 & 0.39 \\
\hline
\end{tabular}


Table 52 Technical Change Estimates

\begin{tabular}{|l|c|c|c|c|c|}
\hline & 1979 & 1982 & 1986 & 1989 & $1979-89$ \\
\hline Scale-Augmenting Change & $13.6 \%$ & $21.0 \%$ & $2.8 \%$ & $-1.1 \%$ & $19.1 \%$ \\
\hline Fuel-Augmenting Change & $-4.5 \%$ & $-6.7 \%$ & $-3.2 \%$ & $-6.6 \%$ & $-3.5 \%$ \\
\hline $\begin{array}{l}\text { Rate of Scale-Augmenting } \\
\text { Change (annual) }\end{array}$ & $13.6 \%$ & $21.0 \%$ & $2.8 \%$ & $-1.1 \%$ & $1.8 \%$ \\
\hline $\begin{array}{l}\text { Composite Rate of } \\
\text { Technical Change }\end{array}$ & $4.2 \%$ & $5.2 \%$ & $0.1 \%$ & $-23.4 \%$ & $0.7 \%$ \\
\hline Returns to Scale & 0.67 & 0.68 & -0.2 & 7.2 & 0.82 \\
\hline \hline
\end{tabular}

Despite the appearance of a homogeneous fuel source for power-generation technologies, there are some broad differences in the sample that merit discussion. Some coal-fired boiler units are rated as "supercritical," denoting a capability to withstand higher temperatures and pressures than conventional units. Joskow and Rice $(1985 ; 1990)$ have examined in detail the technological advance issues of these units. Another subclass of coal-based technologies is represented by integrated, coal-gasification combined cycle plants (IGCC). To test for the effects of these on the estimates of technical change, a number of models were specified with intercept shifts and interactive effects based on technology types. Generally, the regression results revealed little interactive effects and only broad parameter shifts. Table 5.3 contains a sample of the effects on the regression coefficients using the pooled sample. It also contains the estimates of technical change associated with these effects in the case of shifts in the reduced form relations whether the technology was supercritical or IGCC, relative to conventional coal.

The performance of these alternative regression specifications is not markedly different from the pooled results of Table 5.1. Vintage effects are now diluted across technologies and the level of statistical significance on the price ratio variable is virtually unchanged. ${ }^{(a)}$ The technical change interpretations are, however, somewhat more revealing. Scale-augmented technical change in IGCC units is over twice the rate for conventional units, occurring at an annual rate of 2.6 percent versus 1.0 percent. This is in contrast with 1.8 percent from our initial results for all units, undifferentiated by type. The composite rate of technical change is similarly affected with the differentiation. IGCCs possess a composite rate of change of 1.0 percent

(a) Interactive effects to allow for different slopes on the price ratio effects were insignificant statistically. 
Table 5.3 Model Extensions

\begin{tabular}{|c|c|c|c|c|c|}
\hline & \multicolumn{2}{|c|}{ Pooled Regression } & \multicolumn{3}{|c|}{ Technical Change Estimates } \\
\hline & $\begin{array}{l}\text { Thermal } \\
\text { Efficiency }\end{array}$ & $\begin{array}{l}\text { Optimal } \\
\text { Scale }\end{array}$ & & $\begin{array}{l}\text { Regular } \\
\text { Coal }\end{array}$ & $\mathrm{IGCC}^{1}$ \\
\hline Constant & $\begin{array}{c}8.97 \\
(0.23)\end{array}$ & $\begin{array}{l}10.5 \\
(1.4)\end{array}$ & Scale-Augmenting Change & $10.1 \%$ & $26.4 \%$ \\
\hline Price Ratio & $\begin{array}{r}-0.051 \\
(0.052)\end{array}$ & $\begin{array}{c}1.03 \\
(0.31) \\
\end{array}$ & Fuel-Augmenting Change & $-1.7 \%$ & -0.043 \\
\hline Vintage & $\begin{array}{r}-0.017 \\
(0.011)\end{array}$ & $\begin{array}{l}0.085 \\
(0.64)\end{array}$ & $\begin{array}{l}\text { Rate of Scale-Augmenting } \\
\text { Change (annual) }\end{array}$ & $1.0 \%$ & $2.6 \%$ \\
\hline $\mathbf{R}^{2}$ & 0.45 & 0.51 & $\begin{array}{l}\text { Composite Rate of } \\
\text { Technical Change }\end{array}$ & $0.4 \%$ & $1.0 \%$ \\
\hline S E R & 0.059 & 0.34 & Returns to Scale & 0.83 & 0.84 \\
\hline
\end{tabular}

whereas there is only 0.4 percent for regular coal. Both of these indicated results seem to produce a reasonable boundary around the undifferentiated, pooled results of Table 5.2, while preserving almost identical implications for the unit returns to scale. In sum, technical change for technical advance in IGCC seems to reflect considerably higher rates than the more mature, conventional technologies. 


\subsection{Conclusions}

This study has addressed several primary issues related to modeling and measuring the rate of technological change in electricity production using coal-fired technologies. First, a case is made for continuing to explore the empirical implications of the engineering-production function approach due to Ling (1964) and Cowing (1974). Second, a data source is advanced, which more closely represents true ex ante data. Both of these extensions help to address some major limitations of other, earlier studies on technical change and productivity in the electric-utility industry.

Our empirical findings fall well within reasonable ranges: scale-augmenting technical change appeared to be occurring at nearly a 2 percent annual rate over the decade of 1979 to 1989. This seems to reflect the tendency for technical progress to augment capital over other factors with techniques to enhance thermal efficiency, although this was an era of declining real energy prices. In the net, however, the outlook for rapid technical change in coal technologies is less than hopeful: the composite rate of technical progress was only 0.7 percent over our study period.

Our analysis revealed further that the pace of technical advances was uneven, over such a comparatively short period as $\mathbf{1 0}$ years, although this was a far less turbulent decade than the preceding one. Suitable estimates for long-run technical change needed to be conditioned on durations longer than employed here, however. This may pose significant obstacles in terms of uniformity and quality of data. Additionally, technical change appeared to be occurring at a disparate rate even within the broad category of coal-fueled generation. While "on average" the fuel-share weighted rate of composite technical change was estimated to be only 0.7 percent per annum, the rate of IGCC was slightly higher (1.0 percent) and for regular, conventional coal units slightly lower ( 0.4 percent).

How suitable are these estimates for long-run modeling of the electric-power sector? On the one hand, our parameter estimates are within the reasonable range of magnitudes found in many other studies. For screening analyses and costing for customary rate-making, our estimates possess considerable utility. On the other hand, extrapolation of our estimates for very long-run simulations (like those typically underlying global-emissions policy analyses) is probably subject to the usual caveats. The very long-run is probably much too long to expect the 
dominant production technology to remain within the same technical parameter advanced here. Broadening the array of distinct technologies along the line of the engineering-production function, and with comparable ex ante data remains a challenge for further work.

However, at least two promising areas are apparent. The first area would be that in which the model specifications were extended to more flexible forms, thus permitting a broader characterization of technical change. Extending the pooled sample of information to span as many more years as possible would also be desirable in this context. The second area would be that in which engineering-production techniques were applied to other classes of generation technology. This would be a straightforward and informative endeavor, as the results achieved to date indicate. 


\subsection{References}

Averch, H., and L. L. Johnson. 1962. "Behavior of the Firm under Regulatory Constraint." American Economic Review 52(5):1052-1069.

Boyes, W. J. 1976. "An Empirical Examination of the Averch-Johnson Effect." Economic Inquiry 14(1): 25-35.

Chenery, H. B. 1949. "Engineering Production Functions." Quarterly Journal of Economics 63(3):507-531.

Christensen, L. D., and W. H. Greene. 1976. "Economies of Scale in U.S. Electric Power Generation." Journal of Political Economy 85 4):655-676.

Courville, L. 1974. "Regulation and Efficiency in the Electric Utility Industry." Bell Journal of Economics and Management Science 5(1):53-74.

Cowing, T. G. 1974. "Technical Change and Scale Economies in an Engineering Production Function: The Case of Steam Electric Power." Joumal of Industrial Economics 23(1):135-152.

Cowing, T. G. 1978. "The Effectiveness of Rate-of-Return Regulation: An Empirical Test Using Profit Functions." Chapter 5 in Production Economics: A Dual Approach to Theory and Applications, eds. M. Fuss, and D. McFadden, pp. 215-246. North-Holland Publishing Company, Amsterdam.

Cowing, T. G., and V. K., Smith. 1978. "The Estimation of a Production Technology: A Survey of Econometric Analyses of Steam-Electric Generation." Land Economics 54(2):156-186.

Dhrymes, P. J., and M. Kurz. 1964. "Technology and Scale in Electricity Generation." Econometrica 32(3):287-315.

Diewert, W. E. 1971. "An Application of the Shephard Duality Theorem: A Generalized Leontief Production Function." Journal of Political Economy 79(3):481-507.

Economic Report of the President. 1992. U.S. Government Printing Office, Washington, D.C.

Electric Power Research Institute (EPRI). 1979. Technical Assessment Guide. Electronic Power Research Institute, Palo Alto, California.

Electric Power Research Institute (EPRI). 1982. Technical Assessment Guide. Electronic Power Research Institute, Palo Alto, California. 
Electric Power Research Institute (EPRI). 1986. Technical Assessment Guide. Electronic Power Research Institute, Palo Alto, California.

Electric Power Research Institute (EPRI). 1989. Technical Assessment Guide. Electronic Power Research Institute, Palo Alto, California.

Gollop, F. M., and J. R. Roberts. 1981. "The Sources of Economic Growth in the U. S. Electric Power Industry." Chapter 5 in Productivity Measurement in Regulated Industries, eds. R. Cowing, and R. Stevenson, pp. 107-143. Academic Press, New York.

Gollop, F. M., and J. R. Roberts. 1983. "Environmental Regulations and Productivity Growth: The Case of Fossil-fueled Electric Power Generation." Journal of Political Economy 91(4):654674.

Joskow, P. L. 1987. "Productivity Growth and Technical Change in the Generation of Electricity." The Energy Journal 8(1):17-38.

Joskow, P. L., and N. L. Rose. 1985. "The Effects of Technological Change, Experience, and Environmental Regulation on the Construction Cost of Coal-Burning Generating Units." RAND Journal of Economics 16(1):1-27.

Joskow, P. L., and N. L. Rose. 1990. "The Diffusion of New Technologies: Evidence from the Electric Utility Industry." RAND Joumal of Economics 21 (2):354-373.

Kavanaugh, D. C., and Simpson, M. 1981. "Scale Economies in the U.S. Steam-Electric Power Industry." Presented at the 56th Annual Western Economics Association Meetings held in San Francisco, California, July 2-8, 1981.

Ling, S. 1964. Economies of Scale in the Steam-Electric Power Generating Industry. NorthHolland Publishing Co., Amsterdam.

Nelson, R. A., and M. E. Mohar. 1983. "Regulation, Scale Economies and Productivity in Steam-Electric Generation." International Economic Review 24 (1):57-78.

Nelson, R. A. 1987. "Alternative Technological Indices and Factor Demands in the Electric Powder Industry." The Energy Journal 8(3):135-147.

Nelson, R. A. 1986. "Capital Vintage, Time Trends, and Technical Change in the Electric Power Industry." Southern Economics Journal 53(2):315-332.

Nerlove, M. 1963. "Returns to Scale in Electricity Supply." In Measurement in Economics, ed. C. Christ. Reprinted from Stanford University Press, Palo Alto, California. 
Petersen, H. C. 1975. "An Empirical Test of Regulatory Effects." Bell Joumal of Economics and Management Science 6(1):111-126.

Shephard, R. W. 1970. The Theory of Cost and Production Functions. Princeton University Press, Princeton.

Spann, R. M. 1974. "Rate Return Regulation and Efficiency in Production: An Empirical Test of the Averch-Johnson Thesis." Bell Journal of Economics and Management Science 5(1):38-52. 
Appendix A: Data Sources 


\section{Appendix A: Data Sources}

This appendix is devoted to a discussion of the sources of data used to support the econometric estimation of the engineering-production function for coal-fired steam electric generation. The derivation of measures for the variables used in the specifications is also summarized. The primary data source is the Electric Power Research Institute's (EPRI's) Technical Assessment Guide (TAG), (1977, 1979, 1984, and 1989). Background on this data and the rationale for its use in the estimation of technological change is contained in Chapter 3 of this report.

The following coal-fired technologies are represented in the estimation data base:

- coal-steam - subcritical, wet limestone flue gas desulfurization (bituminous and subbituminous)

- coal-steam - supercritical, wet limestone flue gas desulfurization (bituminous and subbituminous)

- coal-steam pulverized, flue gas desulfurization

- coal-steam, atmospheric fluidized bed combustion

- coal-steam, pressurized fluidized bed, combined cycle

- coal gasification, combined cycle.

For each generation technology, the TAG reports a broad range of cost and performance characteristics. The data base developed for this analysis contains observations on the following variables:

- nameplate rating in megawatts (MW)

- number of generation units for the constructed plant

- date of availability of technology for commercial orders

- first commercial service year

- total plant cost, in dollars per kilowatt $(\$ / \mathrm{kW})$

- total plant investment (includes allowance for funds during construction [AFDC]), in $\$ / \mathrm{kW}$

- $\quad$ startup and land cost, in $\$ / \mathbf{k W}$

- total capital cost, in $\$ / \mathrm{kW}$ 
- fixed operation and maintenance (O\&M) cost, $\$ / \mathrm{kW}$-year

- incremental O\&M cost, variable in mills/kilowatt hour (kWh)

- incremental O\&M cost, consumables in mills/kWh

- net heat rate (full, average load), in British thermal units (BTU)/kWh

- $\quad$ planned outage rate, in $\%$

- unplanned outage rate, in \%

- equivalent unplanned outage rate, in \%

- $\quad$ operating availability, in $\%$

- equivalent availability, in \%

- capability ratio

- unit life, in years

- region of location.

Data from the TAG that deal with the financial variables that a system planner would also require for screening analysis cover:

- Cost of equity capital (preferred and common) to the regulated utility

- Cost of debt

- Capitalization ratios

- Nominal capital recovery factors

- $\quad$ Expected general inflation

- Real capital recovery factor

- Levelized fixed charge rates.

The final data retrieved from the TAGs also include delivered coal costs by region and by bituminous and sub-bituminous types to match with the generic location of plant sitings.

The TAG data are supplemented with cost/price deflators from the Economic Report of the President, (1992), and covered the following variables: 
- Implicit GDP price deflator

- Implicit fixed investment, non-residential price deflator

- Implicit fixed investment, non-residential structures deflator

- Implicit fixed investment, non-residential durables deflator.

The price deflators are transformed into two-year moving averages to approximate the convention adopted uniformly in the TAG of stating costs as of the end of the calendar year. The moving average served to match the price deflators with the year-end expenditures in transforming nominal costs into constant-1989 dollars for the analysis.

The EPRI cost data (deflated) and the performance data were used to develop the following variables:

- Annualized capacity cost using total capital cost (adjusted for unit number scale economies with EPRI guidelines) and the plant's capital recovery factor, expressed in terms of a Kwhequivalent basis with the use of the planning plant capacity factor.

- Levelized fuel cost using fuel prices and expected escalation over the life of the plant, present worth factor and levelizing factor.

- Levelized variable O\&M cost using non-fuel O\&M cost and escalation assumptions.

- Levelized variable cost as the sum of fuel and non-fuel variable costs, levelized.

- Effective capacity using nameplate capacity rating, adjusted to the capability ratio to obtain effective MW of capacity available to serve load. 
PNL-10383

UC-350

\section{Distribution}

No. of

Copies

\section{OEFSITE}

2 DOE/Office of Scientific and Technical Information
No. of

Copies

ONSITE

DOE Richland Operations Office

D. D. Green

8 Pacific Northwest Laboratory

D. C. Kavanaugh

T. L. Gilbride

Publishing Coordination

Technical Report Files (5)

Distr. 1 